Introduction to the Sociology of Development 
Andrew Webster is also co-author of Introductory Sociology (with Tony Bilton, Kevin Bonnett, Philip Jones, Ken Sheard and Michelle Stanworth) 


\title{
Introduction to the Sociology of Development
}

\author{
Andrew Webster
}

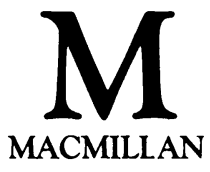




\section{(C) Andrew Webster 1984}

All rights reserved. No part of this publication may be reproduced or transmitted, in any form or by any means, without permission

First published 1984 by

\section{MACMILLAN PUBLISHERS LTD}

Houndmills, Basingstoke,

Hampshire, RG2 I 2 XS. and London

Companies and representatives

throughout the world

Filmsetting by Vantage Photosetting Co. Ltd., Eastleigh and London

British Library Cataloguing in Publication Data

Webster, Andrew

Introduction to the sociology of development.

I. Economic development -Social aspects

I. Title

$3^{\circ 6^{\prime}} \cdot 3 \quad \mathrm{HD}_{75}$

ISBN 978-0-333-37129-9

ISBN 978-1-349-17667-0 (eBook)

DOI 10.1007/978-1-349-17667-0 
For Helen and Matthew 


\section{Contents}

List of Figures

List of Plates

$x$

Acknowledgements

I The Sociology of Development I

I. I Introduction I

I.2 Aims of the text 4

I.3 Key sociological questions

2 Measures of Inequality and Development

2. I Introduction I5

2.2 The concept of poverty 18

2.3 The Third World and its poverty 22

2.4 The basic needs strategy 34

2.5 The perception of development from below 37

3 Modernisation Theory 4 4I

3. I Introduction 4 I

3.2 The theoretical origins of modernisation theory 44

3.3 Modernisation theory 49

3.4 Summary of modernisation theory and its implications

3.5 The critique of modernisation theory $\quad 56$

3.6 Conclusion 62 
4 Theories of Underdevelopment $\quad 64$

4. I Introduction 64

4.2 Marx's theory of capitalism and class conflict 65

4.3 The exploitation of the Third World: an account of merchant capitalism, colonialism and neo-colonialism

4.4 Explanations for underdevelopment $8 \mathrm{I}$

4.5 Conclusion

5 Population, Urbanisation and Education

5. I Introduction

5.2 Population

$5 \cdot 3$ Urbanisation

5.4 Education and Industrialisation

5.5 Conclusion

6 Political Development

6. I Introduction

6.2 Theories of political development: Nationbuilding and State Formation

6.3 Third World politics: The analysis of instability I 35

6.4 Conclusion

7 Aid and Development: Who Benefits?

7.I Introduction

7.2 The sources of aid

7.3 Economic rationale for aid

I 5 I

7.4 The failure of aid to stimulate growth

I 5 I

7.5 The critique of aid

I 56

7.6 Conclusion

8 Gritique of Industrialisation

8. I Introduction

8.2 The populist challenge to industrialisation

I 70

8.3 The ecological critique of industrialisation 
8.4 Alternative technology $\quad$ I82

8.5 Conclusion $\quad 186$

9 Conclusion $\quad 188$

9. I Introduction I 88

9.2 An outline of development models and 'policies' I 89

$9 \cdot 3$ Conclusion 204

Bibliography 206

Author Index $\quad 215$

$\begin{array}{ll}\text { Subject Index } & 219\end{array}$ 


\section{List of Figures}

I.I The three worlds 5

2. I Share of global income by population 28

2.2 Famine comes from income insecurity 33

4. I The triangular trade 7 I

4.2 The colonial empires IgI4 75

7.I Aid? From hand to mouth $\quad$ I55 


\section{List of Plates}

I The global market: the multinationals in Lebanon 7

2 The modern media as a vehicle for tradition 8

3 Absolute poverty I7

4 The shanty town I IO 


\section{Acknowledgements}

The notion of dependency is, as the reader will discover, a central theme much criticised in the sociology of development. It is, however, a concept that properly describes the relationship between an author and those who, through their generosity and good humour, make a text like this possible.

There are a number of friends and colleagues who should be given special mention for the very great assistance they have given me. Tony Bilton commented on the manuscript with a blend of firm critique yet positive encouragement that helped keep me going when the typical uncertainties of authorship crept in as the project progressed. My thanks go, too, to my other sociological colleagues at CCAT without whose scholarship, wit and coffee this work might have been completed more quickly but less happily. Gavin Kitchling offered a number of judicious remarks about Chapter 8, helping me to avoid some factual errors and unwise generalisations. Thanks also to Tim McPhee for many helpful suggestions. Any errors that remain are of course deliberate mistakes to check the reader's attentiveness.

My students at CCAT, at both A level and degree, have been a source of much inspiration for the way in which my ideas in this area have developed. Some were good enough to comment on parts of the early drafts of this text. I am also very grateful for the support of the Research Committee and Library staff at CCAT, and to Sue Barnard and Jenny Connor for their speed in translating manuscript to typescript.

My editor at Macmillan, Steven Kennedy, has given much assistance and encouragement throughout the project as well as sound advice, and to him and his support team I am particularly grateful.

Finally, I must thank my wife, who not only helped me with the indexing and bibliography but also assisted in a way that ensured my dependency was a positive pleasure.

Cambridge

A.J.W.

May 1984 